\title{
Freedom of Information Bill: open government or closed minds?
}

\author{
by Lord McNally
}

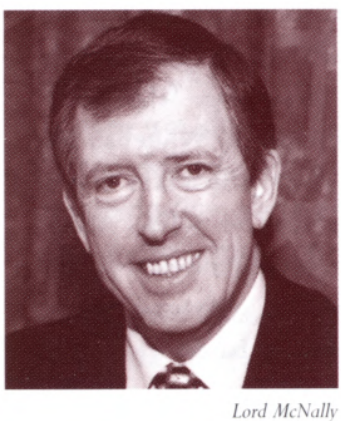

A lecture given to the Institute of Advanced Legal Studies by Lord McNally on 28 February 2000.
$\mathrm{O}$ 17 December 1997, the President of the International Commission of Jurists, Justice Michael Kirby, gave a lecture on Australian experiences of freedom of information in which he warned against seven deadly sins which can undermine a commitment to freedom of information. I will list them as he gave them and ask you to keep them in mind as I report to you the state of the Freedom of Information Bill as it approaches the half-way stage in its passage through Parliament.

Justice Kirby's seven deadly sins were:

\section{Strangled at birth}

'Do not underestimate the danger of your freedom of information proposals. Many a White Paper has come to nothing or emerged into final legislative form a pale shadow of its former self.

The longer the delay in the passage of the long-heralded UK Freedom of Information Bill the greater the risk that Sir Humphrey will have the last laugh yet again.'

\section{Retaining secrets}

'Pretend to support freedom of information but provide so many exceptions and derogations from the principle as to endanger the achievement of a real cultural change in public administration.'

\section{Exemptions}

The third deadly sin is 'surrendering too many requests for exemptions.'

\section{Costs and fees}

'Rendering access to freedom of information so expensive that it is effectively put beyond the reach of ordinary citizens.'

\section{Decision-makers}

'Undermining the essential access to an independent decision maker.'

\section{Interpretation}

For this 'the judiciary and not the politicians, may be answerable'. But remember 'judges also grew up in the world of official secrets and burcaucratic elitism.'

\section{Changing administrative culture}

Beware believing that 'the passage of freedom of information legislation is enough of itself to work the necessary revolution in the culture and attitudes of public administration.'

$\mathrm{Mr}$ Chairman, please remember those warnings were given over two years ago after the Labour Government had been in power less than six months. It could have been given tonight after 1000 days of New Labour, so apposite are his warnings. But let us begin at the beginning.

When the Labour Party won its landslide victory in May 1997 most political observers expected that at long last a quartercentury-old pledge to introduce a Freedom of Information Act would quickly be redeemed. After all the pledge had been in every Labour electoral manifesto since 1974. It had been a key element in the pre-election Constitutional Committee Report drawn up by the Labour Party and the Liberal Democrats and chaired jointly by Robin Cook and Robert Maclennan. That report committed both parties to a range of constitutional reforms aimed at reinvigorating the political process.

Indeed it is worth remembering that the raison d'être for the Cook/Maclennan Committee was a shared analysis by Labour and the Liberal Democrats that our democracy was in danger because of public disenchantment with politics and politicians.

How to re-connect the voters with governance was the task we set ourselves. Our solution was a range of proposals to make government more open, more relevant and take it closer to the people.

As a member of the Cook/Maclennan Commission I can look back on the thousand days of the Blair Government with some satisfaction. Many of our key proposals have become law with commendable alacrity:

- Scotland has its Parliament and Wales and Northern Ireland their Assemblies; 
- the European Convention on Human Rights is now part of our domestic law;

- elections to the European Parliament and in Scotland, Wales and Northern Ireland have all taken place under systems reflecting proportionality rather than 'first past the post';

- London will, in May, have a strategic authority, again elected by a system reflecting proportionality and a mayor of its own;

- other major cities and local authorities are being encouraged to initiate a range of experiments in how we vote and how we govern ourselves at local level;

- the first stage of House of Lords reform, removing all but a hundred hereditary peers, has been carried through;

- the House of Commons has adopted a number of minor reforms aimed at making its work more cffective.

That does not mean that we are in a position to tick the box marked constitutional reform and assume that the job is done. For one thing, the Liberal Democrats at least would like to see public opinion tested in a referendum on proposals for introducing systems of PR into voting for both Westminster and for local government. Indeed it is ironic that the government has conceded PR for the largest local authority; London, yet digs its heels in against reform at the level of government where 'first past the post' elections have created a string of one-party states and with them the associated corruption. There have been too many cases of Labour's 'rotten boroughs' not to see the case for PR at local government level as overwhelming.

But the other reason why the box marked constitutional reform cannot be ticked is because freedom of information, which was scen as the cement that bound together all the other reforms, remains in cloubt. What is more, we are told on good authority that Mr Alistair Campbell can only describe priority given to constitutional reform in terms of obscene expletives. Even Mr Blair has, apparently, cooled to freedom of information on the advice of his old friend Bill Clinton, who has found freedom of information American-style something of a burden.

So where are we now on freedom of information? The Bill, which was introduced, somewhat belatedly for a 25-year-old commitment, into this session of Parliament has just completed its Committee Stage in the House of Commons. The Bill thus far has had a rather worrying ancestry. Immediately after the General Election the responsibility for freedom of information was put in the hands of the Cabinet Office and the Chancellor of the Duchy of Lancaster, David Clark. He produced a consultation document, 'Your Right to Know', which was widely acclaimed by all those who had campaigned for a Freelom of Information Act as a principled and progressive approach to the task at hand. Indeed so principled and progressive was Clark's approach that he was promptly sacked from the Cabinet, and responsibility for freedom of information was transferred to the Home Office. Now it might have been a little unworthy of me to suggest, as I did at the time, that putting the present Home Secretary in charge of freedom of information was like asking Count Dracula to look after a blood bank

Nevertheless the decision to move freedom of information from the Cabinet Office to the Home Office was strange in any circumstances. At a stroke the task was moved from an office with general oversight over Whitehall and a specialist minister to one of the most overworked and accident-prone departments in the government. The suspicion from the very beginning was that
Jack Straw's bricf was to recapture the ground which David Clark's White Paper had given away. It is an interesting 'Catch 22' that, although we know what the various political parties, interest groups and pressure groups have to say about freedom of information, we have no idea what advice has been given by the mandarins of Whitehall.

All that we know is that between the departure of Clark and the publication of Straw's own discussion document, and the draft Bill in the spring of 1999, the government did a quick Uturn on the road to Damascus. Instead of being the flagship bill of New Labour's commitment to open up government, it took on more and more the appearance of a damage-limitation exercise. Yet the Bill now before Parliament is not totally absent of all merit. It recognises for the first time a statutory right to information in place of the previous effective presumption in favour of secrecy. Indeed it was to breakdown what many acknowledge as a culture of secrecy not only in Whitehall but throughout British Government at all levels which was one of the key motivating forces behind reform. The public cannot enjoy their full rights, nor can elected representatives bring the executive and the bureaucracy to full account, without a right to know the information on which decisions are based.

The Bill also extended coverage of public authorities far further than any previous non-statutory codes or guidelines. The wide application of the Bill to central and local government activities and public authorities is a major step forward. After all it is not by selling arms to Iraq that most citizens come in contact with government. It is often the petty injustices and the high-handedness of the minor bureaucrat which outrage and alienate $\mathrm{Mr}$ and Mrs Joe Public.

Nevertheless, following the high expectations raised by the Clark White Paper, the Bill as it stands is a major disappointment. Clark's proposals outlined just seven specified interests such as defence, international relations or policy development that required some degree of protection from total openness. However, it explicitly repudiated the approach of exempting whole categories of information. It argued instead that disclosure should be considered on a contents basis and, in the main, only refused when 'substantial harm' would be caused to onc of the specified interests.

The Bill rejects Clark's minimalist approach to exemptions. Instead of the White Paper's seven it now features twenty-three and gives the Home Secretary power to create still more by order. Furthermore, the commitment to judging each document on a content basis is gone. Many exemptions are 'class' exemptions, conccaling information by category rather than through any analysis of whether disclosing it might actually cause any damage at all. These exemptions are not subject to any 'prejudice' test and disclosure can be withheld even if not harmful. Where the government has reduced the 'harm' test from 'substantial harm' to 'prejudice' it may bear reiteration of the point that the 'class' exemptions are not even subject to this watered-down test.

In addition the fairly stiff hurdle of 'substantial harm', which the Clark White Paper proposed and which government had to clear to justify withholding information, has been reduced to one of 'prejudice', substantially widening the amount of information each exemption can conceal.

An example of an objectionable class exemption is that which exempts all information that has at any time been gathered in an 
investigation which might have led to a criminal prosecution. Campaigners have argued that this could allow the Health and Safety Executive to withhold information about a rail disaster. The families of those who died on the Marchioness could be refused information about what happened that night. Finally, a family like the Lawrences, trying to find out whether or not the police competently investigated the murder of their son, could find their way blocked by this exemption. It is worth remembering that Recommendation 9 of the Macpherson Report into the Stephen Lawrence case proposed that:

'A Freedom of Information Act should apply to all areas of policing, both operational and administrative, subject only to the 'substantial harm' test for withholding disclosure.'

In other words, not only was a 'class exemption' rejected, but the report advocated the stiffer prejudice test. As it is, whether the case was closed, whether a prosecution was ever brought, the fact that information was gathered by a public authority in an investigation where a prosecution might have resulted would allow the information to be withheld forever.

Two other examples of the breadth of the exemptions which feature the 'prejudice' test concern defence and international relations. Tivo journalists have won awards from the Campaign for Freedom of Information for their work.

In 1994 a Chinook helicopter crashed in the Mull of Kintyre, killing all those on board including several senior officers. The pilots were later blamed and accused of gross negligence. Tony Collins of Computer Weekly has uncovered information suggesting that Chinooks elsewhere have been affected by software failure, therefore casting doubt on the culpability of the pilots. Moreover he revealed that MPs had been misled about the crash. Information relating to this might be protected cither by the class exemption for investigations or by the exemption for information which might prejudice defence.

Sticking with defence, freelance journalist Rob Evans, writing in The Telegraph, has uncovered evidence that thousands of spare parts for Trident have gone missing. Will this kind of exposure of gross maladministration still be possible, under the catch-all exemption for defence matters?

Evans also exposed the fact that in the very recent past Britain was giving free military training to some 53 nations. Such information would be very interesting to anyone who wished to judge whether or not Britain's foreign policy was truly ethical. The exemption for information which might prejudice relations between the UK and any state, or the interests of the UK abroad, might be used to conceal it.

In their defence, government ministers have argued that the great benefit of the Bill is that it will open up government to prevent the petty secrecies which cause most irritation and provide most cover for incompetence and maladministration. This may well be so; but it is the cause celèbre which tests the merit of a system and which in the past has all too often seen the British Establishment diving for cover:

Another exemption allows information to be withheld if it would 'prejudice the commercial interests of any person'. Campaigners have argued that this would allow information about an unsafe product to be withheld simply because people might stop buying the product.
By far the most objectionable exemption is the class exemption relating to all matters involved in policy development. Liberal Democrats have argued that a key aim of freedom of information should be to open up the process of government to public scrutiny and debate. Accordingly, we have argued that at the very least all the facts and figures upon which a decision is based should be released after a decision is made. For example: free post for Mayor of London election campaign; government refusal based on 'estimates' of cost from $£ 15 \mathrm{~m}$ to $£ 40 \mathrm{~m}$ - true cost probably about $£ 2 \mathrm{~m}$. This would allow individuals and lobbying groups to examine whether or not government decisions were based on comprehensive and correct data. And this is not asking for the moon. The former Cabinet Secretary Lord Butler told the Lord's Select Committee of which I was a member that such a separation of fact and opinion would be possible. The Republic of Ireland's Freedom of Information Act 1997, s. 20(1), only restricts access to factual information, its analysis, or scientific or technical advice where considerable prejudice would result. New Zealand's Official Information Act 1982, s. 9, has been applied in a similar manner:

During my time in the Lords (and I have now been in the Lords longer than my four years in the House of Commons) I have served on two ad hoc select committees; one looking at the implications for the Civil Service of the Thatcher reforms of the 1980s and the other at the Home Secretary's proposals for freedom of information. Those experiences, along with my own time as a special advisor inside Whitchall between 1974 and 1979, convince me that we need a holistic approach to Civil Service reform, reform of Parliament and freedom of information.

During the 1980s, with very little reference to Parliament and, let it be said, very little interest by Parliamentarians in the process, the Thatcher Government carricd through reforms in public administration and the way public services are organised which went well beyond anything which would be described as new management techniques.

The most decisive of the Thatcher reforms was privatisation - moving vast sectors from public to private ownership and vastly reducing the number of civil servants along the way. It may be said that Mrs Thatcher's main motivation was cost cutting and efficiency. However the revolution was carried on under John Major, with the hiving off of Civil Service functions to semi-autonomous agencies underpinned by the rights of the Citizen's Charter. Contracting out and market testing became part of reforms which saw the gradual erosion of a unified and career-distinctive Civil Service.

Much of this was with clear intent. Mrs Thatcher dic not doubt that parts of the Civil Service were a Rolls Royce machine provided by Rolls Royce minds. What she doubted was whether such Rolls Royce minds were all needed locked-up in an overlarge public service or would not better be deployed in more entrepreneurial activities in the private sector:

The House of Lords Committee on which I sat from 1997 to 1998 looked at whether the Thatcher/Major reforms had destroyed the essential ethos of the British Civil Service - the independence of thinking and advice which had marked it out for its quality since the Northcote Trevelyan reforms a century and a half before. We came to the conclusion that that essential ethos had survived the turbulence. We also asked the question 
implicit in a long period of one-party rule, namely whether the Civil Service had been so politicised by the 'Is he one of us?' approach to preferment as to render it incapable of serving new political masters.

That question was answered in 1997 when the change of government was achicved with great professionalism and seamless service.

Things were not the same however. The new government brought with it a new breed of political advisors, many of whom had spent years working with their ministers as a kind of shadow civil service. In addition the government established numerous task forces to help develop policy, bringing into Whitehall powerful and influential figures from the private sector. There has been much gnashing of teeth about the specific role of both the political advisors and of the task forces.

I belicve that the political advisors and policy advisors, given proper accountability and limits on their action, can be an invaluable source of fresh ideas both in the development and cxplanation of policy. The task forces, meanwhile, arouse concern because they may provide a convenient link into government decision making for the private sector in a way which interlinks too closely with financial and other support for the governing party.

To see where New Labour is coming from in their approach to the Civil Service it is necessary to go back twenty years to the previous Labour Government. In 1982, David, now Lord, Lipsey, who had been my colleague in Downing Street when I headed the No.10 Political Office, produced a Fabian pamphlet entitled 'Making Government Work' which recorded the prevailing mood in the Labour Party after its 1979 defeat:

'Practically before the door of No. 10 had closed on the new' incumbent an inquest was underway. It rapidly revealed a potential culprit. Labour's carefully worked out policies, the account went, had been systematically sabotaged by a conservative (if not Conservative) Civil Service.'

To be fair to David he quashed that view of history as a myth; a view with which I concur. But that pamphlet did make a number of points which are familiar today, twenty year later. He said that 'Civil Service advice needs to be augmented by alternative sources of ideas and analysis'. The pamphlet also stated 'from civil servants and ministers alike we want to see a broad and generous openness' and, perhaps most crucially of all, it clearly said that the difficultics which outsiders face in influencing government and the lack of ministerial involvement in key decisions all result in part from 'the obsession with secrecy displayed throughout British government.'

If the commitment to open up government to outside influence via task forces and political and policy advisers is part of a 'never again' determination that a Labour government should remain master of its own destiny, so too is the commitment to more open government.

That is why I believe that it is the cause of radical and reforming government which has most to lose by the passing of a weak and ineffective Freedom of Information Act. I have already paid tribute to the amount of constitutional reform promised by Cook/Maclennan which has already reached the statute book. But most of that was carricd out by the momentum of a government returned to office after eighteen years in opposition. Already we are told that the prime minister fears the law of unforeseen consequences as his constitutional creations refuse to dance to his tune. But those are not unforeseen consequences. They are the direct consequences for those who want to see power squeezed out of Whitehall and back into state, regional and local government. Already we have seen in Scotland a consultation document produced by a coalition government proposing just the kind of Freedom of information bill from which Jack Straw has retreated. The Scottish legislation advocates three key elements which we will continue to press at Westminster:

(1) facts and figures behind policy decisions should routinely be released after a decision is taken;

(2) exemptions should be more narrowly drawn and whenever possible the test of 'substantial harm' should be used;

(3) the Information Commissioner should be able to order disclosure in the public interest. The Scottish Information Commissioner will even be able to order the release of information falling within exempted categories, if justified in the public interest, subject only. to a veto by the Scottish Executive.

The Scottish Consultation Document, 'An Open Scotland', uses the term 'substantial prejudice' rather than 'substantial harm':

'Our use of 'substantial prejudice' is intended to make clear that information covered by a contents based exemption should be disclosed unless prejudice caused would be real, actual and of significant substance."

I suspect the word 'prejudice' is used to dovetail with UK legislation, though most campaigners would prefer the word 'harm'; but neither substantial prejudice nor substantial harm are on offer in the Straw Bill.

The Scottish Information Commissioner will have power to order disclosure of any information covered by a harm-tested exemption. In the case of class exemptions (often remaining to be consistent with the UK legislation) the Commissioner's final say will be subject only to the collective veto of the Scottish Cabinet. Such a collective veto has existed in New Zealand since 1987, but has not been used. Between 1982 and 1987 New Zealand allowed individual ministers to overrule the Ombudsman (our Commissioner), as will be the case in London. However, that individual veto was used so often that they later had to amend their system. New Zealand's experience shows that London's proposals do not give the Commissioner strong enough powers; Scotland's do.

Broad and gencral exemptions are less problematic as long as their provisions can be overridden by a strong and independentlyadministered public-interest test. Unfortunately, as I have already pointed out, the Bill does not offer this. Several of its excmptions are not subject to the public interest test at all. Where the test is applied, the final say on whether or not information should be released does not lie with the Information Commissioner but with the minister or public authority involved. This is a clear conflict between the personal and public interest.

Two good quotes regarding the power of the Commissioner to order disclosure in the public interest come from the two select committees which examined the Bill:

'If the ultimate decision whether information is exempt from such a right of access is made by a Government Minister or public authority 
rather than by an independent arbiter, the law may be regarded as a statement of good intentions, but it is not a Freedom of Information Act as that term is internationally understood.' (House of Lords)

In the Commons the Public Administration Committee said:

'In this crucial sense the Bill continues the present discretionary system of the Code of Practice - it is "open government" and not "freedom of information".'

The Information Commissioner must have powers similar to that of counterparts in Ireland and New Zealand to order disclosure. I know that the Lords Select Committee on which I sat were most impressed by the evidence of the Irish Commissioner on this matter and a related consequence. The Irish Commissioner was under no doubt that his having the power to order disclosure made for anticipatory compliance, i.e. the bureaucracy knew that the game was up and started to act in a more open way rather than to resist disclosure. The Irish Commissioner did believe, however, that having inherited the culture of secrecy from the British it was also necessary to train their bureaucracy in the ways of open government. As Justice Kirby warned in his seven deadly sins, disclosure is not just by Act of Parliament it is also an attitude of mind. It would be nice to think that the Whitehall Civil Service, government agencies and other public bodies were already putting in mechanisms to train their staff into the culture of open government, rather than combing the Bill like accountants do a finance bill for exemptions to be exploited.

From what one hears of the government behaviour in the Commons committee they have either gone as far as they intend to go or are reserving any further concessions for the Lords.

So let me close by trying to anticipate the reception that the Bill will get in the Upper House. First, the good news for those who hope that the Lords will be able to extract further concessions from the government.

The House of Lords is in no mood to accept lectures from the government about us being an undemocratic and un-elected second chamber with no mandate to thwart the wishes of the elected chamber. We are what this government made us. Our powers are the powers which the elected chamber wished upon us only last year. In that respect it is a secondary and indirect mandate; but a mandate nevertheless. If the government had wished the House of Lords to have no power it should have brought forward a bill which would have done just that. Instead it left us with the powers of a revisory and an advisory chamber. If ever there was a bill where we should use those powers, the Freedom of Information Bill is it.

The bad news is that although the government cannot get all its own way in the Lords in the way it can in the Commons with its 180 majority, we must not assume that it will be entirely without friends. Although the Conservative Opposition have undergone a Pauline conversion of their own on freedom of information, their back-benches and the cross-benches may not be as solid as we might wish on these matters. Ex-ministers tend to remember their old love affair with secrecy and there are plenty of retired mandarins on the cross-benches ready to defend the old ways.

Nevertheless there will be a concerted effort in the Lords to make the government think again so as to open up the background to decision making, narrow to an absolute minimum areas of exemption, restore the substantial harm hurdle and beef-up the powers of the Commissioner. We will also want to write onto the face of the Bill a 'Purpose Clause' which will spell out Parliament's intention for the courts, the bureaucracy and the general public. It is interesting to note that Elizabeth France, the Data Protection Registrar and Information Commissioner Designate, has argued the nced for a clear set of principles to guide access decisions under the Frcedom of Information Act.

Section 4 of New Zealand's Act states the purpose of the Act as being to 'increase progressively the availability of official information to the people of New Zealand'. The clause has been useful in helping to ensure that there is usually a presumption in. favour of disclosure by the Ombudsman and courts.

Without such an intentions clause, the suspicion will continue that this is an exercise in damage limitation and the culture of secrecy will remain.

If they really mean it the government must be a cheer-leader for openness. For too long in Britain, the Civil Service and government have been co-conspirators in keeping things secret. Having few and narrow exemptions and a strong Commissioner should both be essential parts of the government demonstrating its commitment to frecdom of information. In the absence of either of those, a Purpose Clause is the very least that they can offer to bolster the moral authority of the Bill, and increase its impact on the culture of secrecy.

Now I am well aware that a Freedom of Information Bill may seem to the general public no more than an Anoraks' Charter, of interest to Guardian leader writers and the Institute of Advanced Legal Studies. I do not believe that. The battle lines which are being drawn as the Bill moves to the House of Lords are at the dividing line between what Lord Hailsham described as 'elective dictatorship' and accountable, democratic, parliamentary government.

In his lecture, Justice Kirby quoted with approval another Australian judge, Justice Paul Finn. This Justice Finn quote goes to the heart of the matter:

'To the extent that the power of the people is devolved upon institutions and officials under our constitutional arrangements, those officials and institutions become the trustees - the fiduciaries - of that power for the people. The reason is obvious enough. In a fundamental sense the power given to officials, elected and non-elected alike, is not their own. It is ours. They hold it in our service as our servants. In short our officials exist for our benefit.'

Quite so. And that concept of 'service' in governance can only be fulfilled on the basis of a freedom of information act which both extends the right to know and changes the culture of secrecy.

I hope and believe that the Lords will not flinch from its duty and will insist that the present Freedom of Information Bill is inadequate for the needs of a modern democracy. In truth, the existing Code of Practice is in some respects broader than the provisions of the Bill; in particular, in respect of factual information and policy making. What is needed is a $21 \mathrm{st}-$ century act for new circumstances. We are moving into the age of interactive democracy. A third of our population already has access to the Internet, and the government's intention is for a wired-up Britain. 
We are told that already underway is the Knowledge Network Project whose overall aim is to use the new technologies to explain the government message without going through "the distorting prism of media reporting', according to a Cabinet Office paper leaked to The Guardian.

If government is intent on providing such weaponry for its own defence, it is essential that Parliament and people have increased access to information if the present uncqual balances of power between the executive and Parliament and the executive and the citizen are not be distorted further.

I referred earlier to the Law of Unforeseen Consequences and how it is now tempering the reforming enthusiasm of the Blair Govermment. But I repeat these consequences are not unforeseen - they are intentional. We are sceking a range of reforms which will diminish and disperse the power of Britain's over-centralised state. We are secking to empower the citizen and to make Parliament stronger and more effective in its check on the exccutive. We are sceking to make decision-making at all levels more transparent and more accountable.

All this will make government in terms of the concept of British Government as an elected dictatorship more difficult. Good, but it will also rescue the government from isolating itself behind walls of secrecy, increasingly blaming the media and the messengers for not understanding, until a combination of hubris and alienation brings them crashing down.

In February 1996, a year out from his landslide victory, Tony Blair said this:

'It is time to sweep away the cobwebs of secrecy which hang over far too much government activity.
The traditional culture of secrecy will only be broken down by giving people in the UK the legal right to know.

When he made that speech it cannot have been his intention to provide Britain with one of the world's most timid and restrictive freedom of information acts to be enacted by a Westminster-style democracy. Yet that is what is heading for the Statute Book unless the House of Lords intervenes. There is an old saying in the Southern States of the USA:

'It is sometimes difficult to remember that the idea was to drain the swamp when you find yourself up to the armpits in alligators.

Well, all governments very quickly find themselves up to the armpits in alligators. It has perhaps taken this one a little longer than most.

When the 18th-century radical, John Wilkes, announced that he intended to publish a newspaper, The North Briton, he was asked, 'How free is the British Press?' He replied, 'We are about to find out.'

Today we can ask how determined is the House of Lords to use its increased legitimacy to reject poor and inadequate legislation and to remind the government that the swamp of secrecy remains undrained?

The answer is the same: 'We are about to find out.'

Lord McNally

Liberal Democrat Peer; Vice-Chairman of Shandwick

\section{Doing Business in Europe}

Doing Business in Europe is an easy-to-follow guide to European tax and legal systems. It is an ideal first port of call for companies and their advisers operating or planning to operate across Europe or in particular jurisdictions.

\section{Your subscription includes}

- Loose-leaf - 2 volumes updated 6 times a year covering key western European countries

- Newletter - European Newletter, 10 issues a year, and Eastern European Newletter*, issued monthly *The Eastern European Newletter is also available as a separate subscription

\section{Key benefits}

- Easy-to-use - standard template in the loose-leaf makes country-by-country comparisons easy.

- Up-to-date - frequent updating and regular newsletters provide the latest information on western and eastern European developments.

- Authoritative - combined with CCH.New Law's own expertise, the authors are from leading firms of lawyers and accountants dealing with the specific countries covered.

- Accessible - comprehensive topic indexing provides ready access to the text.

- Wide reaching - each country division contains broad coverage of various subjects, e.g. tax, company law, employment law and competition. 